\title{
CHALLENGES AND OPPORTUNITIES OF THE NETWORK-CENTRIC WARFARE ON THE NATIONAL DEFENSE SYSTEM OF ROMANIA
}

\author{
Mihai-Marcel NEAG \\ "Nicolae Bălcescu" Land Forces Academy, Sibiu, Romania \\ mmneag@yahoo.com \\ George MOGOȘ \\ "Nicolae Bălcescu" Land Forces Academy, Sibiu, Romania \\ smash1995@yahoo.com
}

\begin{abstract}
The article discusses the network-centric warfare, presenting it as a new concept designed for fighting future wars and all types of conflicts with a predominance of technology as opposed to the traditional personnel, logistics and tactics elements matrix. It is, indeed, worthy of further investigation, research and development, and testing because its technical potential is very promising and novel. The basic premise of this type of warfare is, in our opinion, that it is a totally new and evolved way of conducting a vast area of military operations and that the practices of the past are somewhat irrelevant and inefficient. Network-Centric Warfare concept represents the third generation of combat development and therefore, the future of warfare in general. The actual combat platform itself represents the first generation; the linking and automation of the individual platforms into a command and control (C2) system constitutes the second generation; the third, network-centric warfare, is catalogued as a system of systems dynamically connected with distributed and dynamic information processing.
\end{abstract}

KEYWORDS: warfare, defense, network, digitization, security

\section{Introduction}

Recent discoveries and conquests in the field of information and communication technology, as well as the ability of individuals or organizations to use these opportunities have changed the nature of the world in which we live.

In all human activity, including war, the time needed to access and gather the amount of information needed to make a decision appropriate to the purpose was drastically reduced through information and communication technology, while the volume of information available has exponentially grown (Popa, 2004).

It becomes easy to understand that, with all these evolutions, a new type of war will arise in the form of the NetworkCentric Warfare (NCW). With the advent of this new concept differences will arise in the field of increasing the fighting capacity and this fact is due to the NCW 
implications in several fields, such as: the physical domain (the space where the actions will take place), the informational domain (the place where the information itself is created, manipulated and disseminated) and the cognitive domain (refers to the mind of the participants and how they understand).

The methodological and theoreticalscientific support of the research is based on the application in complex of theoretical and empirical methods that allowed to identify the characteristics of the present and future operational environment from a higher perspective, specific to the fields of military sciences.

The empirical method allowed us to observe the main characteristic features of the operational design involved in the networkcentric warfare, from which we extracted the strengths and weaknesses, which opened the way for us to develop advanced conceptual models in interoperability conditions.

The comparative method served to reveal the distinct differences of the different holistic approaches of the operations, which allowed us to analyze how the concept of network-centric warfare may or may not resist the contemporary paradigms of the modern confrontation environment.

In the research conducted in this article were used, in complex, the analysis and synthesis, abstraction and rationalization, induction and deduction.

2. National Defense System of Romania and the Implications of the Network-Centric Warfare

The realization of the new structures of the National Defense System (NDS) adapted to the conditions of the NCW must be based on several principles, which fully exploit the availability of the action in the network. The most important principles to be applied in structuring a NCW Force are the following:

- operationalization of management and action structures;
- Force standardization;

- use of the Joint structure model;

- NATO compatibility;

- elimination of redundant steps;

- network structuring.

The Romanian statute itself, as a NATO member country, necessarily requires that the Force destined for the NCW lead to be based on the Joint - NCW structuring model, using the effect of the information - speed - mobility triad, thus giving to the combined operations a power multiplied, by a rapid maneuver and perfect control of the battlefield, through mobility, precision and flexibility. Joint type configuration, high level technical equipment and new operational training will give the NCW Force superior powers. The joint type structuring of the NCW Force for joint multinational operations obliges the creation of groups of variable size and composition, which include elements of all categories of forces (Calopăreanu, 2009).

Determining their size and composition will require a thorough study by the specialists, which will take into account the requirements of operational mobility, flexibility, interoperability, capacity to support and rapid adaptation to changing situations in the theater (International Business Publications, 2017). Modular structures of this type are achievable at the level of the Romanian Army, as well as at the level of all the components of the National Defense System.

Joint structuring will consider both the possibility of carrying out independent and joint military actions with the allies, but also the possibility of modifying the composition of the forces during the operation.

The structural model for NCW, which could be adopted, would include:

- subunits of transmissions and infrastructures that apply the concept;

- interoperable and interface elements (where no NATO means); 
- modular striking structures (network of combat entities);

- logistical support structures;

- structures for network generation, management, security and administration;

- research systems (sensor network), warning, surveillance and control of air traffic;

- command and control systems in C4I component.

\section{Standardization, Modularization and Flexibility in the Realization of the NCW Force Structures}

Regarding the standardization and modularization of structures, to conduct joint network-based operations, independently or together with NATO forces, the structures of the national defense system constituted for this purpose will have to be standard structures. (Center for Strategic Security Studies, 2003).

The essential element to be considered is that increasing the effectiveness of NCW forces groups acting independently, individually or jointly, depends on the coordination of standardization activities with NATO, especially in the field of specific NCW systems and equipment, of the modules that will be achieved.

These changes will take place within the standardization process, which is already underway, but will require more consistent financial efforts over a longer period of time.

Standardization will ensure interoperability on the battlefield in the network, cooperation, establishing the operational information needs, defining the technical configurations for organizing the work in the network.

The standardization of the future NCW structure will aim at:

- equipping the group of forces and the fighter, in the field of observation, communication, protection, mobility, support and equipment;
- exchange of information in the field of structuring, conception and doctrine of NCW conduct, of the specific strategy and tactics.

The modular organization of the group of future forces that will act in the network will ensure:

- timely maneuver;

- continuous logistics, with the possibility of sustainability in the theater;

- high combat capacity with rationally established resources;

- an increased firepower;

- increased mobility;

- anticipatory-preventive management.

It will provide:

- all the conditions for a synergistic action in the operational field;

- increased autonomy;

- ability to perform a wide range of missions, with specialized and special forces, reduced and performing.

The new type of organization provided by the concept of NCW will allow for anticipatory self-regulation (of type feed-for), which will ensure the decisive advance in action against the opponent. At the same time, through the close connection to the network, it will increase the accuracy of a hit against the enemy.

The flexibility of future modular structures generates multifunctionality, an initiative in relation to the types of action for which it was constituted, but it is known that the main quality of this type of structure is the proactive (preventive) character, which allows the force module to overtake the opponent in action. In the atypical confrontation with terrorist elements and groups, a modular structure following the type of NCW has the highest chances of success.

The optimal modular combat structure for NDS will have to be established so that the ratio between the technical, material, human and financial efforts made and the results obtained will be optimal. 
Modularization is a question of time and budgetary funds, cooperation with the USA and the continuation to new parameters of the interoperability process of structures and functions with NATO structures and forces.

The modularization approach will be carried out in a faster way after the full integration of our country in the Alliance. This fact could have a very serious motivation considering the fact that our country participates every year with combat and training structures in international missions. At the same time, the modularization process is favored by the decision of the grant up to $2 \%$ of the GDP for the national defense and for the development and aquisition of new and performant technologies and weapons. It would be possible, within a reasonable time horizon, precisely because part of the NCW support exists, although extremely weak (some sensors, STAR, some powerful weapon systems), and what is added, step by step, can be subordinated to the purpose of achieving the force structure necessary to conduct the new type of war or the new types of operations.

At the same time, the new formula for the realization of the NCW Force structures could lead to either the restriction or the dissolution of the major states of the categories of forces, with the creation of specific Joint Command and operational groups. The disappearance or restructuring of the redundant hierarchical echelons (General Staff of category of forces, army corps, division) is, moreover, a problem that has to be studied carefully, in order not to make hasty decisions.

In order to achieve the last two principles, namely the operationalization of the management and action structures and the network structuring, it is necessary to elaborate a new doctrine for using the NCW concept and to digitize the informationdecision-making flow.

\section{A New Doctrine for the NCW Forces}

The process of elaborating the doctrine of the use of the NCW concept consists, on the one hand, in connection with the Alliance's doctrine, in deepening and concretizing, at doctrinal level, the strategic partnership with the United States of America and, on the other hand (but strictly conditioned by this dimension), in the particularization of this doctrine in relation to the vital interests of our country, with the vulnerabilities, challenges, dangers, risks and threats that Romania faces or could face (Center for Strategic Security Studies, 2003).

In this sense, the main foundations of the doctrine of using the NCW concept are the following: political, economic, technology, information, and military.

\subsection{Political}

The transition from the classic type threats - state interests against state interests (state against state) - to those of asymmetrical type (which are structured in networks) requires a different organization of the action. The political decision, by which the defense (security, protection, expression and even imposition) of one's own interests, especially the vital ones, must be connected to the new realities required by the globalization process, to the new vulnerabilities resulting from the establishment of informational type societies, to new threats. In a security environment characterized by strategic partnerships between the great actors, the diminution of the risks of wars between states, the accession of a large number of states to the European Union, to NATO, to international economic, political and cultural bodies of all kinds, the old doctrines state-to-state political confrontations are no longer meaningless. There is a growing need for coalition of states against common threats, such as network threats, terrorists, drug trafficking and organized crime. 
The political foundations of the NCW define the new type of engagement in the fight, its limits and reasons. It is a selective, punctual, limited and very precise, under conditions of maximum security, with the support of the partners and, usually, in the coalition.

\subsection{Economic}

The principles that apply, at present, in the modern economy are those of complex dynamic determinism, treated by chaos theory, in which economic unity and economic network matter.

It was found that the most efficient economic structures are not the large hierarchical enterprises, but the so-called "B" type enterprises, which more easily adapt to the conditions of production and sale. Moreover, the unprecedented development of information and communication technology (ICT) - based systems allows and, at the same time, demands the transition, in all fields (not only economic), to a new type of organization, the one in the network. The Romanian economy, in deep reconstruction, for the moment does not allow and does not necessarily demand the transition to an organization of production and action in the networks, although there is a perspective, in the sense that the modernization of the communication and information systems began, the networks were formed of computers, and development projects and programs are based on the introduction of high tech.

\subsection{Technology}

The NCW concept is strictly dependent on high tech and an appropriate doctrine. The technology required for such a project exists. It is produced in the United States, Japan, the European Union, and some of the components may be products even in the country. Regarding the technological foundations, the following must be considered: the increased capacity of the communication systems and the possibility of improving them; eventual Romanian participation in the European program for the production of modern weapons and equipment (combat platforms, sensors); the policy of continuous introduction into the economy and high tech security systems.

\subsection{Information}

The information becomes the support of any action, the operationalization of any system. The quantity and quality of the information, the speed with which it flows, the security and the speed of the decision are decisive.

\subsection{Military}

The army and the other elements of the NDS of Romania are organized on the principle of hierarchy. The transition from the ubiquity and omnipotence of this principle to the application of the network organizations principle implies a real mutation in the military field. Hierarchical echelons will disappear or be restructured, action modules will be created, all of which will be reduced to the connection, in the same system, of the three network grids (sensor grid, comand and control system grid and execution platform grid - for combat)

\section{Digitization, a Need for} Succesfull Decision-Making

The digitization of the informationaldecision-making flow will involve the transition from natural to binary, logical languages, so that the information flow will benefit from the very high speed of data transmission, the immense storage capacity and the processing of information, the quality, the fidelity and the security of digitized communications systems.

The digitization can be carried out in at least two ways:

- connecting existing information systems (sensors, command and control systems, battle platforms, etc.), through the interface, to the digitized systems; 
- development of new systems (information sensors, multi-purpose sensors, Command, Control, Communications, Computers, and Intelligence - C4I - systems, weapon systems) digitized.

Connecting current systems to computer networks is not a very good solution, but an imposed one. No one, not even the American state, can afford to give up existing systems, hundreds of means of combat and immediately create new, digitized ones. And then they proceed to digitize them. This is how the Americans proceeded with some of the weapon systems of the $4^{\text {th }}$ Infantry Division. This is how we proceeded with the MiG 21 aircraft, which became the MiG 21 Lancer and the IAR 330 helicopter. The digitization consisted in the creation, on these means, of electronic systems (avionics, fire management systems, sensor systems, etc.) capable of connecting the respective weapon systems to the digitized command and control systems.

\section{Conclusions}

The confrontation environment has evolved permanently, adding new features and developing new dimensions with the evolution of society and technological progress, which has always been the spearhead of practical applications in the military field.
When adopting the NCW concept, we consider that a very careful analysis of each system should be done, so that only those means (sensor systems, weapon systems, etc.) that have a perspective and that are compatible (at least for one) should be digitized with NATO systems. Digitizing such systems may, on the whole, cost more than creating new, truly efficient ones (for example, digitizing current analog coastal radars).

Making or even purchasing new, digitized systems is the ideal solution. This must be done within the limits of resources, and these are extremely limited. However, such an endowment solution cannot be renounced.

The new concept applied to military action will provide flexibility, operational capabilities and omniscience allowing immediate and simultaneous reactions at strategic, operational and tactical level because, regardless of the degree of dispersion and the distance at which the forces are located, it is possible to hit simultaneously various targets: centers of gravity, critical vulnerabilities, operational elements, tactical forces, etc. At the same time, the NCW makes it possible to precisely focus the fire wherever it is needed, which will mean increased possibilities to effectively influence the enemy's behavior and perceptions in all dimensions of the combat space.

\section{REFERENCES}

Anand, D., Raja, Ch., \& Rajan, E. G. (2011). Network Centric Warfare - Concepts and Challenges. CiiT International Journal of Networking and Communication Engineering, Vol. 3, Issue 14, Coimbatore, India: Coimbatore Institute of Information Technology, available at: https://www.researchgate.net/publication/327111113 Network_Centric warfare - C Concepts and challenges, accessed on 20 January 2020.

Calopăreanu, G. (2008). Teorie și practică în operațiile bazate pe efecte. Revista de Știință Militară, Vol. 2, Issue 15, 39-47, București: Editura Secţiei de Ştiinţă Militară a Academiei Oamenilor de Ştiinţă din România, available at: https://www.mapn.ro/ evenimente/uploads/pdf/20090211 101614 432bc467b828d29f3b657af9f7cad967.pdf, accessed on 15 January 2020. 
Center for Strategic Security Studies. (2003). Aspecte teoretico-metodologice și modalități practice de aplicare a conceptului "război bazat pe rețea" în Armata României, corespunzător "structurii" de forțe 2007. București: Editura Universităţii Naţionale de Apărare „Carol I”, available at: https://cssas.unap.ro/ro/pdf studii/rbr.pdf, accessed on 15 January 2020.

International Business Publications. (2017). Romania Army, National Security and Defense Policy Handbook. Vol. 1, Strategic information and developments, p. 121, Washington, DC, USA: International Business Publications, available at: https://books.google.ro/books?id=m1qtDwAAQBAJ\&pg=PA121\&lpg=PA121\&dq=razboiul + bazat + pe + retea + network + centric + warfare\&source $=$ bl\&ots $=$ Nez6bnf9P4\&sig $=$ ACfU3U2vcr ZA24-wyIX3KvLi6j3sD1tJ0Q\&hl=ro\&sa=X\&ved=2ahUKEwjw eT5JLnAhVk SoKHYbn ADYQ6AEwCXoECAoQAQ\# $\mathrm{v}=$ onepage $\& \mathrm{q}=$ network $\% 20$ centric $\% 20 \& \mathrm{f}=$ false, accessed on 20 January 2020.

Popa, M. (2004). Războiul bazat pe reţea (RBR) - componentă a revoluţiei în problemele militare. Anuarul Academiei Forţelor Terestre, Nr. 3, 241-248, Sibiu: Editura Academiei Forțelor Terestre. 